\section{On redundancy}

\author{
John Launer
}

I recently lost my job as a consultant, during a programme of financial cuts. This wasn't as catastrophic for me as it may sound. The job was only part time, and my main work in education is currently secure. I am also close to retirement age and without any mortgage, so I faced few of the risks a younger person might have done. At the same time, I had to deal with the experience of leaving a job against my will. This helped me to understand what so many younger colleagues have been facing during the economic recession.

I had known for a long time that my workplace had to reduce costs significantly, and my own position was vulnerable. I had taken a short service break a couple of years ago and had a fixed contract that was coming up for renewal. I was aware my departure might cause problems for the organisation, since I had set up some projects that would fail without me nurturing them. I hoped it might be possible to set an agreed leaving date well in advance, and plan for a smooth succession. I tried to engage in conversations about all of this. Like so many people in the same situation I found the organisation unable to engage with this.

Under financial pressure, human contact becomes difficult. People are driven by other priorities. Perhaps they fear that a negotiation might carry legal risks. Some simply avoid difficult conversations. For whatever reason, a wall of non-communication comes down. In my own case, I discovered my job was coming to an end when I read the statistical appendix to a departmental circular. A few days later, I found a short typed note in my drawer, confirming that my contract would not be renewed.

Among the different emotions I experienced, the most surprising one was shame. In spite of 17 years of productive work and foreseeing the conclusion, I felt somehow judged and tarnished. My first reaction was to skulk around the building,

Correspondence to Dr John Launer, London Department of Postgraduate Medical Education, London Deanery, Stewart House, London WC1B 5DN, UK; jlauner@londondeanery.ac.uk trying to avoid contact with people. I was also angry at the inflexible way my departure had been determined, not to mention the doublespeak of 'productivity measures' and 'cost efficiencies'. I resolved that I would never set foot in the place again after my job finished. It only took me a few days to realise this was childish. Yet it gave me a hint of what it must feel like to lose one's job in less privileged circumstances, and how appalling a blow to one's self-esteem it can be.

\section{SADNESS}

My role had brought me into contact with every department and probably a wider range of personnel than almost anyone else in the organisation. I was a familiar face around the building. Perhaps it's a compliment to be likened to the ravens in the Tower of London, or perhaps not, but a few people made that comparison. The warmth of people's reactions to my departure was sometimes in inverse proportion to their seniority. Those in supporting roles-like the receptionists, administrators, secretaries and librarianswere most generous with their time and sympathy. However, one or two normally decent peers whom I had worked with over many years reacted by asking 'But who on earth will now run $X$, or take over $Y$ ?' before remembering to ask how I felt.

Sad to say, some of the most senior people in the place, including the person who had written my dismissal letter, walked past me in the corridor without a word. I recognise that they had to make difficult decisions, and this no doubt played a part in their awkwardness-but it would have been good to talk openly about this. I was grateful to a few people in positions of authority who managed to acknowledge their roles in what had happened, and to apologise for it as well.

There was some dark humour in the situation too. As part of the leaving process, I was required to fill in a 'termination form' - an unfortunate name that I have only come across before when signing medical consent for abortions. In a morbid echo of this, there was a convenient box to tick covering the eventuality of 'died in service'. My employers had to ask me if I could return immediately on a freelance basis to complete one training project (on conflict resolution, ironically). I agreed, but then faced another bureaucratic request that almost snuffed out my last reserves of good will: there was a long application form to become an external staff member-and they wanted me to bring in my passport and two utility bills to establish my identity.

\section{CELEBRATION}

In the end, I decided it was more important to celebrate the past than to mourn a curtailed future. I set a date for a farewell party and made sure to invite all the people I had most enjoyed working with over the years. At my wife's suggestion, I asked a friend to provide entertainment on the harp. A fortuitous trip with the family to Boulogne allowed us to provide some jolly decent 'vin de pays' for everyone, for around two euros per bottle.

I wouldn't have expected when I was a trainee that one of my friends would end up as president of a royal college and another as a postgraduate dean, but such things do happen: both friends were kind enough to say a few words at the party, together with colleagues from the Trust. The greatest pleasure of all was to see as many past colleagues, former trainees and local GPs at the event as current staff. I discovered you can be sad that you have to go, without being sad about anything else.

When all is said and done, it was the right time for me to move on. I still feel privileged to have worked in one of the most highly reputed institutions in the country, alongside some of the brightest and kindest individuals I know. I had the opportunity to teach hundreds of young professionals, in many different disciplines, as well as doing very rewarding clinical work. I shall continue to go into the building from time to time for a number of different activities. I am delighted to have lifelong use of their library. But I still wouldn't wish involuntary job loss on anyone.

Competing interests None.

Provenance and peer review Commissioned; internally peer reviewed.

To cite Launer J. Postgrad Med J 2013;89:122.

Postgrad Med J 2013;89:122.

doi:10.1136/postgradmedj-2012-131738 